\section{Intersections}

Canadian Journal of Music

Revue canadienne de musique
Intersections CANADIAN JOURAL OF MUSIO

\title{
Glenn Gould's Idea of North and the production of place in music
}

\section{Friedemann Sallis}

Volume 25, numéro 1-2, 2005

Northern Perspectives on Music and Culture

URI : https://id.erudit.org/iderudit/1013308ar

DOI : https://doi.org/10.7202/1013308ar

Aller au sommaire du numéro

Éditeur(s)

Canadian University Music Society / Société de musique des universités canadiennes

ISSN

1911-0146 (imprimé)

1918-512X (numérique)

Découvrir la revue

Citer cet article

Sallis, F. (2005). Glenn Gould's Idea of North and the production of place in music. Intersections, 25(1-2), 113-137. https://doi.org/10.7202/1013308ar
Résumé de l'article

Cet article étudie la notion que la musique peut créer un sentiment de localisation et d'identité. Son objet d'étude est Idea of North de Glenn Gould, qui est essentiellement rédigé à partir de textes provenant d'entretiens. Gould manipule ce matériel avec des techniques et concepts permettant la réalisation de ce qu'il appellera par la suite « contrapuntal radio " [radio contrapuntique]. C'est grâce à cette manipulation technique, tout autant qu'en se servant du contenu des textes, que Gould sera en mesure d'exprimer son " idée du Nord ". Un examen critique de ces techniques musicales présentent ainsi un exemple intéressant de la manière dont la musique parvient à produire un sentiment de localisation et d'identité.
Copyright @ C Canadian University Music Society / Société de musique des universités canadiennes, 2005
Ce document est protégé par la loi sur le droit d'auteur. L’utilisation des services d’Érudit (y compris la reproduction) est assujettie à sa politique d'utilisation que vous pouvez consulter en ligne.

https://apropos.erudit.org/fr/usagers/politique-dutilisation/ 


\title{
Glenn Gould's Idea of North and the Production of Place in Music
}

\author{
Friedemann Sallis
}

Everything that Gould did was in a continuum with the original place
and time that he had been afforded as a performer, the concert platform.

Edward W. Said $(1991,33)$

In the lore and legend surrounding Glenn Gould, as well as in much scholarly writing, The Idea of North has always held a special, if somewhat ambiguous place. First broadcast on CBC radio on 28 December 1967, it constituted the initial instalment of three programmes presenting Gould's thought on the effects of solitude and isolation upon individuals or groups. It was quickly followed by The Latecomers (broadcast 12 November 1969), which examines the collective isolation endured or enjoyed by people then living in the outports of Newfoundland. During the ensuing eight years Gould worked on Quiet in the Land (broadcast 25 April 1977) about Mennonite communities of Western Canada and their desire to be in the world but not of the world. These radio broadcasts became what Gould retrospectively called the Solitude Trilogy and are part of a number of programmes produced by Gould over the course of his career. ${ }^{1}$

Evoking Gould's self-declared fascination for Canada's vast northern territories, The Idea of North is regularly mentioned by writers interested in the relation of his work to the Canadian context. ${ }^{2}$ For some, it has acquired almost iconic status (Dickenson 1996, Hjartarson 1996, McNeilly 1996, Fink 1997). In much of this secondary literature there is however a great deal of confusion concerning the work's identity. The Idea of North is usually described either as a documentary, a piece of radio drama, a musical composition or some combination thereof. As a result North and its companion pieces

\footnotetext{
1 Just over a year after the broadcast of Quiet in the Land, Gould was enthusiastically musing about the next instalment, which would have made the Solitude Trilogy a quartet. In a letter dated 4 July 1978 he wrote that the new work would be entitled The Last Puritans, and would examine China and the political dimension of isolation. Unfortunately nothing came of this project (Roberts and Guertin 1992, 237).

2 Like most Canadians Gould never actually travelled above the sixtieth parallel. For a concise presentation of Gould's interest in northern Canada, as well as biographic information related to the composition and production of The Idea of North, see Bazzana (2003, 292-300). For a fascinating discussion of North as a multi-faceted aesthetic category, which permeated Gould's musical thought on many levels, see Markus Mantere's article, entitled Northern Ways to Think about Music: Glenn Gould's Idea of North as an Aesthetic Category, also published in this issue.
} 
of the Solitude Trilogy have been consigned to a kind of conceptual purgatory. ${ }^{3}$ Excluded from the short list of what would best be called Gould's conventional compositions, ${ }^{4}$ they are usually considered to be an aspect of his "radio and television work," and thus merely part of his journalistic output. ${ }^{5}$ As a result these works have been both underrated and misinterpreted. Judgements range from outright rejection to sympathetic ambivalence.

On the one hand, Otto Friedrich summarily dismissed North because it is neither "fish nor foul."

... these are neither abstract sounds being organized according to Gould's aesthetic plan nor are they Gould's words expressing Gould's ideas. Instead of composing a piece of verbal music, ... Gould was simply playing the role of editor, and succumbing, as editors often do, to the idea that what he had edited had become his own creation. (Friedrich 1989, 184)

On the other hand, many authors have enthusiastically embraced what appears to be the sheer multiplicity of North's identity. Early on Geoffrey Payzant $(1978,131)$ described North as a hybrid work involving "music, drama and several other strains, including essay, journalism, anthropology, ethics, social commentary, contemporary history." Two decades later Howard Fink (1997, 35-36) wrote that Gould developed a complex, syncretic form for the works of the Solitude Trilogy and that a unified theory of these works must account for their musical, documentary and dramatic aspects. Recently this reading has been endorsed by Kevin Bazzana.

... The Idea of North was Gould's synthesis of three principles: documentary, drama and music. For all its abstraction and artiness it is a documentary about North, but the documentary material is dramatically charged, conveyed through confrontations of characters with different perspectives, blended evocatively with other sounds. (Bazzana 2003, 301; Bazzana's emphasis)

3 One way around this problem might be to declare the Solitude Trilogy radio art, which it indubitably is. Unfortunately, this widely used term remains woefully undefined, covering everything from the cantata Der Lindenburgflug collectively produced by Paul Hindemith, Kurt Weill and Bertolt Brecht (first broadcast on 27 July 1929) to the multimedia works of the postwar avant-garde (John Cage's Radio Music, Mauricio Kagel's Hörspiele, etc.). In her study of the history and function of music in Italian radio, Angela Ida De Benedictis (2004a, 46-55) concludes that there is as yet no way to define the specifically radiophonic ["specifico radiofonico"] aspect of music that is produced for or transmitted by this medium.

4 This list includes a Bassoon Sonata (1950), groups of short piano pieces (1951-52), a String Quartet (1953-55) and the tongue-in-cheek a cappella choral work So you want to write a fugue (1963).

5 For example the three recordings making up the Solitude Trilogy are entered separately in Nancy Canning's long list of Gould's "CBC Radio and TV Shows" (Friedrich 1989, 385-421). Similar classifications have since appeared in numerous sources (Pincoe and Willis 1992, Bazzana 1994). 
Over the past decade this reading of North has taken on the aura of a canonical interpretation, reinforced no doubt in part because it coincided with so-called post-modern approaches to art and culture, so much in vogue among academics in the waning years of the twentieth century. Indeed, numerous commentators have claimed that Gould himself was a kind of crypto-postmodernist avant la lettre (Bazzana 1997, 84). ${ }^{6}$ Jean-Jacques Nattiez $(1996,29)$ has gone so far as to state that, while Gould was clearly "a modernist in his structuralist conception of the musical work," he was also a precursor of post-modernism with regard to "the content of musical language." This endemic confusion concerning Gould's aesthetic identity has contributed to what Edward W. Said $(1991,34)$ identified as the diminishment of Gould's creative activity, noting that for many "he is known today almost exclusively either as a curiosity or as a very gifted pianist."

In the following, this paper will attempt to persuade its readers that North and the companion pieces of the Solitude Trilogy are an integral part of Gould's "performance activity," which after 28 March 1964 moved from the concert platform to the recording studio. Consequently these works should be considered as musical compositions, that is as aesthetic objects, products of a modernist form of what, in German is called musikalisches Denken (musical thought), and created using specifically musical techniques. ${ }^{7}$ Most of this essay will thus be devoted to sustaining this argument through a close reading of the work's prologue and epilogue, as well as the working manuscripts with which Gould composed North. The essay's coda, evoked in the second half of its title, will then attempt to explain how Gould succeeds in transmitting his "idea" of North musically.

The central claim of this essay is neither original nor new. Gould consistently referred to the works of the Solitude Trilogy as music and used musical terms to describe them. Janet Somerville, who was involved in commissioning North, called it Canada's Finlandia (Bazzana 2003, 303), and more recently Desmond Maley $(2004,35)$ has stated that Gould found his compositional voice in these "contrapuntal" pieces for radio. The purpose of this article is to flesh out this position by bringing forward information extracted from a

6 Bazzana's position is in fact confused. Having identified Gould as a proto-postmodernist, he then spends the next thirty pages arguing that, given Gould's affinities with Arnold Schoenberg's musical thought, he was in fact a musical modernist (Bazzana 1997, 85-127).

7 The aim of this article is not to suggest that all of Gould's radio programmes produced for the CBC should be automatically considered musical compositions. In fact Gould himself threw cold water on such an idea. In a letter dated 10 August 1969 he noted that North and The Latecomers should be considered separately from the rest of his radio programmes by virtue of the fact that he had invested an inordinate amount of time and energy producing them (Roberts and Guertin 1992, 118-119). Fink (1997, 36) states that the programmes on Leopold Stokowski (1971), Pablo Casals (1974), Arnold Schoenberg (1974), and Richard Strauss (1979), together with the three works of the Solitude Trilogy make up an important part of Gould's artistic legacy. Bazzana $(2003,292)$ might want to add The Search for "Pet" Clark (1967) to this list because it was Gould's "first hands-on experience with an artistic brand of radio involving precise and subtle use of montage to unite text and music" (Bazzana's emphasis). 
close reading of parts of the work itself. This analysis will show that understanding North as music is consistent with Bazzana's observation (1997, 55; quoting Richard Taruskin 1995, 10) that Gould's creative activities should best be situated on that "fluid, easily crossed boundary between the performing and composing roles." The fact that Bazzana makes only passing reference to the Solitude Trilogy in his earlier study of Gould's performance practice (1997) is indicative of the problems surrounding the identity of North, which this paper seeks to raise. ${ }^{8}$

Of course, North does not fit easily into current discourse on performance. The work is certainly not a "script" in the sense of a document meant to "choreograph" a repetitive series of real-time aesthetic and social interactions between musicians and an audience (Cook 2003, 206). ${ }^{9}$ On the contrary, North is a polyphonic composition, performed directly to the audience via electronic media (initially the radio and now on commercially available CDs). Like many works produced for the radio, it survives only as a recorded document (De Benedictis 2005, 63). There is no score, making the musical aspects of the work difficult to grasp both analytically and conceptually, a condition North shares with other types of twentieth-century music such as jazz and electro-acoustic music. ${ }^{10}$ To circumvent the problem of coming to terms with North as a recorded performance event rather than as a written score, a study of Gould's working documents conserved in the Glenn Gould Papers at Library and Archives Canada was undertaken by this author. Umberto Eco $(1989,163)$ has pointed out that the comprehension and interpretation of aesthetic form can also be achieved by retracing its formative process, by apprehending or repossessing the form in its state of becoming. Examining North from that perspective puts this project within the purview of a branch of French literary criticism known as textual genetics or genetic criticism. Thus Gould's working manuscripts will not be treated as a mere collection of documents from which isolated facts can be garnered that are in some way related to the creative process. Rather the material will be understood as an avant-texte, ${ }^{11}$ that is to say, an elucidation of the logical systems that involve in the work's creation (Biasi 2004, 43). ${ }^{12}$

8 It is of course entirely legitimate to focus on Gould's activities as a pianist and as an interpreter of repertoire written for that instrument, and Bazzana does examine how Gould's activities as a pianist and a recording studio artist intersect. Unfortunately, his failure to include the Solitude Trilogy in this discussion in a substantive way leaves the impression that this part of Gould's creative activity is somehow secondary and less deserving of interest than his considerable achievements as a pianist. To be fair, in his more recent biography, Bazzana (2003) does present Gould's position, that The Idea of North is a musical composition. This argument takes up about two pages in his book (302-4). However four times as much space (pages 295-302) is used to justify the idea that the work is also a documentary and radio drama.

9 For more on performance as an object of study in its own right, see Kivy (1995), Godlovitch (1998), Bowen (1999), Rink (2002).

10 For more on the problem of apprehending and studying music, which does not require notated scores either for its transmission or its conservation, see De Benedictis (2004b; 2005).

11 The term avant-texte was coined by Jean Bellemin-Noël $(1972,15)$ and defined as "l'ensemble 
One final problem inherent in this project is Gould's own ambiguity with regard to the identity of North. At one time or another he has spoken of the work as a musical composition, as a radio drama and as a documentary. Indeed, in the well-known interview with John Jessop, pointedly entitled "Radio as Music," Gould describes both The Idea of North and The Latecomers within all three frames of reference (Page 1984, 374-88). Though always impressive in their enthusiasm and flair, Gould's writings and interviews can also be rambling and contradictory. Referring to material published in the Glenn Gould Reader, Said candidly notes that it is often "overwritten and underargued."

There are garrulous displays of wit and parody that are, to my taste, both forced and insufferably tedious. Gould was neither intellectually disciplined nor a fully cultivated man, and his learning, for all the exuberance with which he deployed it, often reveals the trying awkwardness of the naïve village philosopher. (Said, 1991, 26-27) ${ }^{13}$

Like many creative artists, Gould was not given to producing closely argued treatises. As a result, the interpretation of his writings can be a difficult and complex task. For all that, these documents can neither be ignored, nor simply taken at face value, and must always be given the careful, respectful attention they deserve.

\section{Documentary, Drama or Music?}

If the term "documentary" has stuck to North, the reason has more to do with the context of its production than with its form or its content. First, Gould has of course stated that North is "technically a documentary" (Page 1984, 392). The technicality resides in the fact that in 1967 Janet Somerville, producer of the series Ideas presented by the Public Affairs unit of the CBC, commissioned Gould to produce a documentary about Canada's northern territories as a special Centennial project. For his services, Gould received the paltry sum of $\$ 1500.00$ (Bazzana 2003, 295-96), and to this day the CBC maintains its copyright on the work. These facts are reflected in the subtitle of the recently released recording of the Solitude Trilogy (1992), which reads "Three Sound Documentaries." Second, the argument that North is part documentary, part drama is often based on the fact that during his early years Gould was exposed to strong Canadian traditions of radio documentary and radio drama (Fink 1997, 36-41; Bazzana 2003, 302). This is undoubtedly true. Like many Canadians of his generation, the CBC had an enormous impact on Gould's sense of identity. However, as important and vital as this influence

constitué par des brouillons, les manuscrits, les épreuves, les 'variantes', vu sous l'angle de ce qui précède matériellement un ouvrage, quand celui-ci est traité comme texte, et qui peut faire système avec lui" (Bellemin-Noël's emphasis).

12 For surveys of the origins, principles and development of genetic criticism, see Lebrave (1992), Grésillon (1994), Jenny (1996), and Hay (2004).

13 Somewhat more charitably, Bazzana $(1997,11)$ notes that Gould's ideas can be inferred more reliably from his musical practice than from his writings and interviews. 
was, it does not follow that North should automatically be understood as either a documentary or as radio theatre.

A recent edition of the New Oxford Dictionary (Pearsall 1998) defines "documentary" as a film, television, radio or photographic programme "using pictures or interviews with people involved in real events to provide a factual record or report." No doubt with a similar definition in mind, Fink $(1997,35)$ felt obliged to observe that normal documentary techniques such as the logical advancing of the theme and the continuous presence and control of an editorial voice are distinctly absent in North, adding that for most of the second half we listen in vain for any clear uninterrupted voice amid the evolving contrapuntal texture. To be sure, North does present fragments of northern experience as reported by the five interviewees. However Gould pointedly refrains from setting these bits and pieces of information in any clearly articulated economic, social or political context. Even the five individuals, carefully introduced by Gould in the prologue, are rapidly disincarnated, becoming disembodied voices (Bazzana, 2003, 299-302): the anonymous stuff with which Gould produced his polyphonic structures. At best one could argue that North is made up of material that could have become a documentary on any number of subjects related to Canada's northern territories: economic development, strategic significance, scientific research, utopian plans versus social realities, race relations, etc. In the end Fink (1997, 39 ) is forced to admit that his argument boils down to "a matter of intention," which he deduces from selected fragments of Gould's writings and interviews. But as noted above, other selected fragments can just as easily be used to explain the musicality of the same segments of North.

Poststructuralists, deconstructionists, new musicologists and post-modernists of all stripes may wish to argue that the above definition of documentary is far too restrictive. Citing the writings of Jacques Derrida and Michel Foucault, some will point out that the definition of documentary resides in the mind of the beholder or listener. Consequently, every film, book, photograph, musical composition, and in the end any isolated fragment of human activity can be understood as some sort of documentary. ${ }^{14}$ Conversely, others will suggest, following Trinh $\mathrm{T}$. Minh-ha, that " $[t]$ here is no such thing as a documentary-whether the term designates a category of material, a genre, an approach or a set of techniques" (Dickenson 1996, 105). As a result of these

14 To paraphrase Steven Feld $(1976,310)$, all films (and by implication all audio-visual documents including North) about people, whether produced by Federico Fellini or some anonymous social scientist, are ethnographic, in that they document something about the people in the film as well as something about those who made it. Applying Feld's perspective to Gould's composition would however mean dragging The Idea of North down to the level of a record of some random social phenomenon. As shall be shown below, North is not about communicating knowledge on territories, peoples or cultures. It is neither an attempt to "capture life sur le vif" nor a "creative treatment of actuality", nor the depiction of "the depth of life as it is actually lived" (Barbash and Taylor 1997, 15-33). Gould's North is an isolated, self-contained work, which Walter Benjamin $(1998,55)$ once described as the "supreme reality of art." 
linguistic games (Lyotard, 1979, 20-24), the term documentary is simply transformed into a mot portemanteau on which anything and everything can be hung with intellectual impunity.

Of course, North can be read as a document issuing out of a given time and place and, like all works of art, it can be used (and abused) to tell us something about the context within which it was created. In this general sense, North is indeed part of southern Canadian discourse on our northern territories and as such reflects the growing interest and apprehension of these territories, which was in fact quite prevalent in Canada during the decades following World War II. Gould was part of that generation of Canadians which first became aware of the geopolitical and social significance of the northern territories. When Prime Minister Louis St. Laurent first created the Department of Northern Affairs in 1953, he aptly noted that "[w]e have administered these vast territories of the north in an almost continuing state of absence of mind" (Friedrich 1989, 173). Paraphrasing Said (1979, 1-4), Gould's work thus participates, through aesthetic means, in southern Canada's economic, social, military, scientific, and political appropriation of this extraordinary place, which most Canadians have never visited and really know very little about. However, that North can be meaningfully related to the context in which it was created, takes nothing away from the fact that it is, first and foremost, an aesthetic object, possessing an objective identity of its own, independent of all possible uses to which it can conceivably be put.

Gould has also stated that The Idea of North is a documentary that "thinks of itself as a drama," and went on to say that its contents were carefully staged as though one were "setting out to compose a play" (Page 1984, 392). And in fact Gould did borrow terms and concepts of the theatre to organise North. This is exemplified below in a synopsis of the entire work prepared by Lorne Tulk, Gould's technical assistant at the CBC.

Eco $(1990,60)$ would argue that in order to justify the claim that North is a piece of radio drama, the analyst must show that the internal coherence of the work has been taken as a parameter for this interpretation. Fink (1997, 40) attempts to do this by demonstrating that the didactic elements of the text are reinforced through "dramatic effects of realism." He notes that the use of train sounds (i.e. wheels, whistles, the dining car, conductors calling passengers on board, etc.) provide realistic effects and in so doing establish a convincing locus within which the characters are portrayed. In his opinion these effects are crucial to the work's message. In fact these sound effects are far more impressionistic than realistic. Their relatively low dynamic level and the sheer monotony of their continuous presence assure that in terms of acoustic décor these sounds fall out of our immediate consciousness relatively quickly, as they no doubt do for those who make the actual trip from Winnipeg to Churchill. ${ }^{15}$ If anything these sounds serve to create a back-

15 The rail sounds fade in near the 4-minute mark and are overtaken at the 50 -minute mark by the 


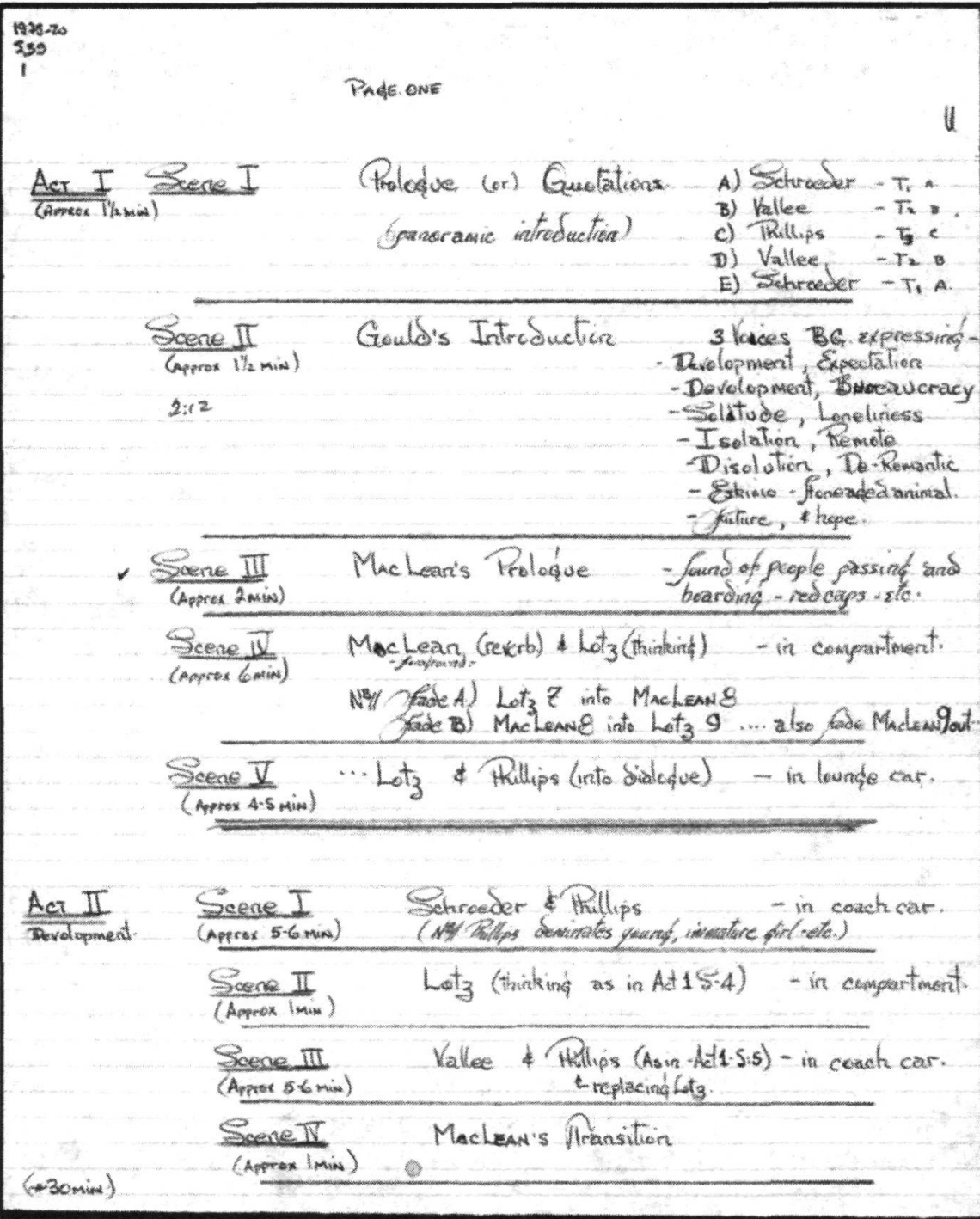

Plate 1a. Lorne Tulk and Glenn Gould, The Idea of North, synopsis, manuscript conserved in the Glenn Gould Papers, Library and Archives Canada, 1979-20/5,39: pages 1-2; @ 1967, 2005, the Estate of Glenn Gould and Glenn Gould Ltd., courtesy of the Estate of Glenn Gould, Glenn Gould Ltd. and Lorne Tulk. 


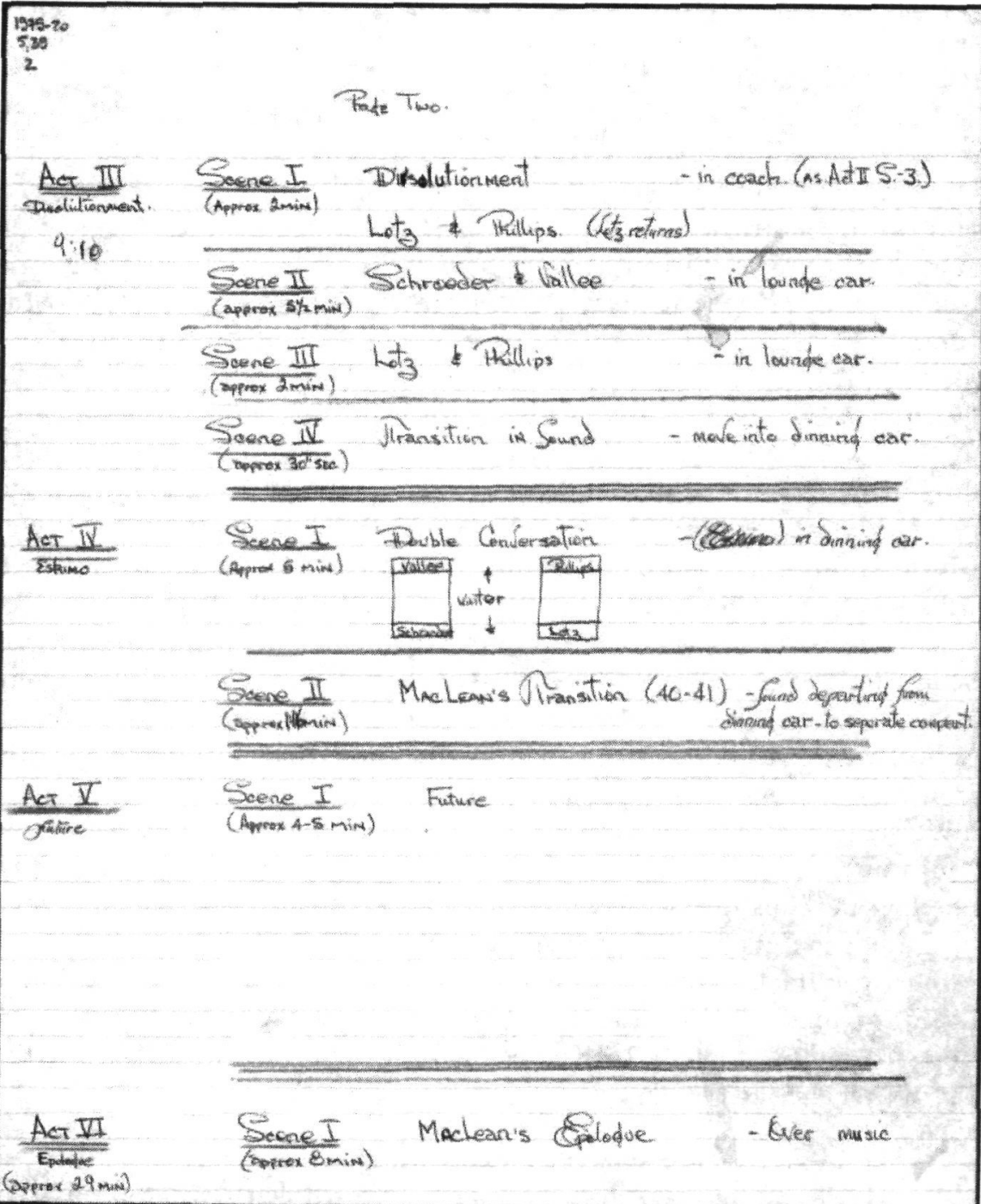

Plate 1b. Lorne Tulk and Glenn Gould, The Idea of North, synopsis, manuscript conserved in the Glenn Gould Papers, Library and Archives Canada, 1979-20/5,39: pages 1-2; (c) 1967, 2005, the Estate of Glenn Gould and Glenn Gould Ltd., courtesy of the Estate of Glenn Gould, Glenn Gould Ltd. and Lorne Tulk. 
ground drone out of which the voices emerge, into which they fade away and against which their intrinsic musicality (melodic qualities, rhythmic delivery, register, etc.) can be heard more distinctly.

Thus the function of these sounds, and indeed all sounds in North, would appear to be far more musical than theatrical. Even the five voices are treated more like instruments, weaving in and out of a polyphonic, rather than dramaturgical, structure. In fact the content of North is really quite thin when examined from a dramaturgical perspective. There is no action, no central conflict and no denouement. ${ }^{16}$ Consequently, Gould's use of the words "drama" or "dramatic" appears to have more to do with musical aspects of the work than with any purported theatricality. This occurs in the carefully modulated ebb and flow of dynamic levels allowing certain voices to come forward while others drop back and also in the abrupt entry of strident, discordant voices. Plate 2 below presents a visual representation of the dynamic relationships between the three voices in the prologue. North begins with the soft, legato voice of Marianne Schroeder. She may well have been chosen because of her ever-so-slight central European accent, which gives her voice a distinctive melodic lilt. After fifty seconds, the atmosphere created by Schroeder's voice is abruptly broken off by the hard, staccato quality of Frank Vallee's voice. Just after Vallee's voice overtakes Schroeder's in terms of decibels, Robert Phillips's voice enters creating a two-voice texture within which it is impossible to separate or even delineate the characters, much less understand the semantic content of their respective texts. Just before the two-minute mark, the dynamic level of the two male voices drops sharply, opening an acoustic space for the return of Schroeder's voice. As can be seen in the upper right-hand corner of Plate 1a, the entire prologue is a palindrome, sublimated in a continuous polyphonic flow of voices, creating a distinctly 'musical' frame of reference within which the rest of the work will be heard. Gould alluded to this when he referred to North as a work of art in the old Wagnerian sense.

The way to do it is to keep all of the elements in a state of constant flux, interplay, nervous agitation ... so that one is buoyed aloft by the structure and never at any moment has time to sit back and say "Oh, well, that's going to be the bridge to Act Two"-you know. (Page 1984, 380)

\footnotetext{
beginning of the third movement of Jean Sibelius's Fifth Symphony. They are thus almost continually present for 46 minutes. The entire work lasts just under 59 minutes.

16 The individuals, whose voices ostensibly constitute the five characters of North, never had the occasion to meet one another either before or even during the production process. Each was interviewed separately and their interaction within North came about solely through careful after-the-fact work with the razor blade on tape undertaken by Tulk.
} 


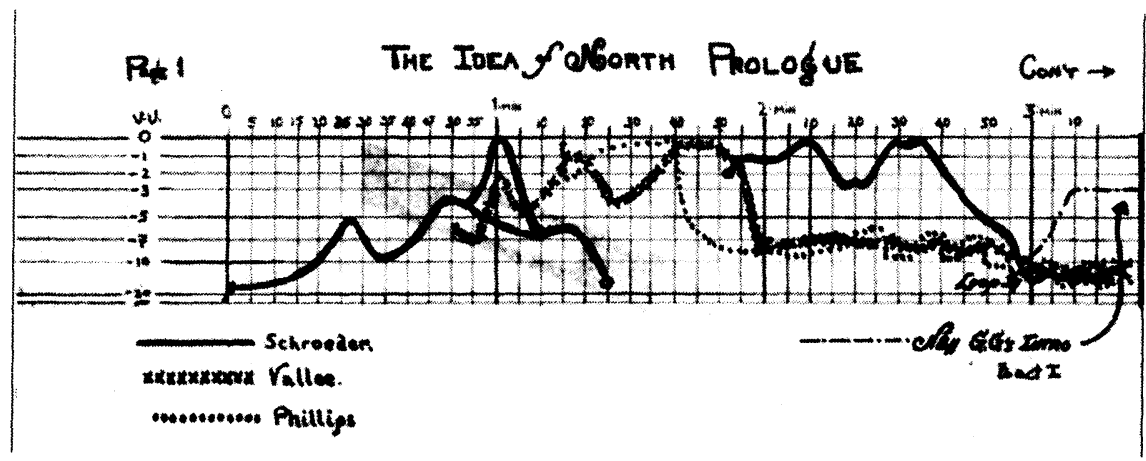

Plate 2. Lorne Tulk and Glenn Gould, The Idea of North, graph of the dynamic structure of the prologue, manuscript conserved in the Glenn Gould Papers, Library and Archives Canada, 1979-20/5,40, 2; (c) 1967, 2005, the Estate of Glenn Gould and Glenn Gould Ltd., courtesy of the Estate of Glenn Gould, Glenn Gould Ltd. and Lorne Tulk. ${ }^{17}$

As noted above, Gould insisted on numerous occasions that North is a musical composition and he accompanied this assertion with commentaries on the new music of his day. In a television interview, given in 1970, Gould observed that the "whole idea of what music is has changed so much in the last five years." Though he made no explicit reference to North, he went on to say that "much of the new music has a lot to do with the spoken word, with the rhythms and patterns, the rise and fall and inclination, the ordering of phrase and regulation of cadence in human speech" (Payzant 1978, 130). Bazzana $(1997,74)$ concurs, noting that Gould considered the works of the Solitude Trilogy "to be musical compositions by the standards of his day, by analogy with contemporary works, like Stockhausen's Gesang der Jünglinge (1956)." Even Friedrich (1989, 184-85) grudgingly admits that "in an era when John Cage composes Imaginary Landscape No. 4 that includes twelve radios simultaneously playing at random, in an era when Steve Reich takes a

17 This plate presents the manuscript that appeared in the original publication of "Radio as Music" (Gould, 1971). It was also reproduced by Fink $(1997,39)$. (NB in both earlier publications, a minor discrepancy exists between the manuscript and the published reproductions. In both the erroneous line indicating that Marianne Schroeder's voice fades after 55 seconds was partially erased). Unfortunately this graph was omitted when "Radio as Music" was reprinted (Page 1984). It is reproduced here because it constitutes an important piece of material evidence supporting Gould assertion that North should be perceived as music and also to correct misleading information concerning the nature of the document. In the initial publication, the graph was labelled a "Sketch by Lorne Tulk", suggesting that it is part of the material left over from the production of North. In fact the graph is a post-production document. In a letter dated 25 February 1971, Gould wrote to Gilles Potvin, the editor of the Cahiers de musique canadienne, that he was having Tulk prepare two sketches to accompany the publication of "Radio as Music" and that the first of these would present details of the prologue (Roberts and Guertin 1992, 136). In German this type of document is called a Hörpartitur (listener's score) and has little if anything to do with Gould's working methods. It is rather a visual interpretation of the work, and as such is eminently musical. Many such documents were prepared during the 1960s and 1970s to accompany the publication of electronic music (see for example Ligeti and Wehinger 1970). 
taped confession of an accused murderer and then reproduces one or two phrases in a googol of repetitions": 18 in an era such as this, Gould's North would also have to be classified as music. From Friedrich's tone of voice, one suspects that he considered all of this just so much experimental rubbish, of little or no consequence for the enduring values of real music. In fact North is part of an impressive group of twentieth century compositions that use the voice in ways other than what Istvan Anhalt $(1984,269)$ called the usual singing mode. ${ }^{19}$ Among these are Mauricio Kagel's Anagrama for soloists, speaking chorus and instruments (1957-58), György Ligeti's Aventures and Nouvelles aventures for voices and instruments (1962-65) and Anhalt's Cento (Cantata urbana) for twelve speakers and recorded voice (1967), a work that Gould knew and admired.

\section{The Composition of NoRTH}

Further support for the argument that North should be considered a musical work can be gleaned from information related to the work's production. Among the Glenn Gould Papers conserved at Library and Archives Canada, one finds 1068 leaves of manuscript material pertaining specifically to this work. ${ }^{20}$ Of this material, four leaves are identified as having been written by Lorne Tulk, three of which are presented above. The rest is in Gould's hand. The collection contains 399 leaves of annotated transcripts of interviews. Each transcript was produced in triplicate (i.e. an original typescript plus two carbon copies). The Library has classified 552 leaves as drafts and rough scripts, most of which are heavily annotated. The remainder of the collection consists of a final text or fair copy of the work (48 leaves) and a miscellaneous group of documents (65 leaves), including concept sketches, production notes, interview questions, liner notes, studio schedules, financial data, etc. (Pincoe and Willis 1992, 27). The manuscript material pertaining to The Latecomers and Quiet in the Land is conserved in similar quantities, and documents similar working methods.

As is often the case with the manuscript material of artists, these documents are interesting because they reveal information about the creative process, which is not otherwise accessible and which can have a significant impact on our understanding of the work. Plate 3 presents a fragmentary concept sketch of the epilogue of North and is interesting on two counts. First, it shows that Gould associated the idea of an "aria" with the epilogue of North, suggesting that the recorded fragments of Wally Maclean's voice should be heard as much for their musical value as for their semantic content. The term is found on two separate leaves both associated with the epilogue, indicating that the idea was more than a passing whim. ${ }^{21}$

18 Friedrich is referring to Come out, composed by Reich in 1966.

19 Anhalt $(1984,7)$ adds that Arnold Schoenberg's technique of Sprechgesang is preceded by an "unbroken tradition of melodrama that reached back to J. J. Rousseau's Pygmalion (1772)."

$20 \mathrm{I}$ am deeply indebted to Maureen Nevins of the Music Division of Library and Archives Canada, who efficiently introduced me to the collection, graciously answered all of my questions and saw to it that my time at the Library was spent efficiently.

21 The other document is a very preliminary sketch, possibly written before Plate no. 3. At the top 


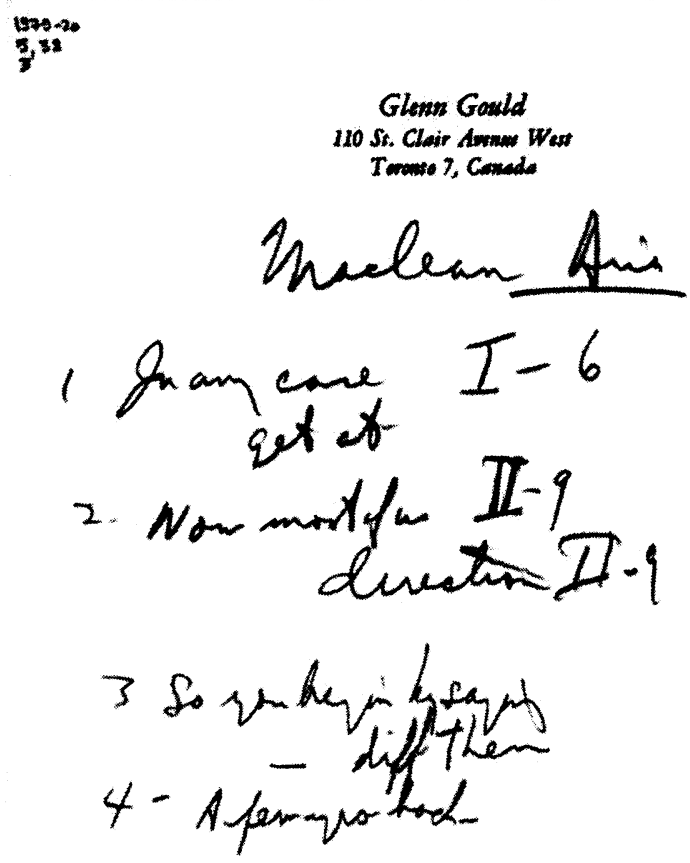

Plate 3. Glenn Gould, The Idea of North, sketch for the beginning of the epilogue, manuscript conserved in the Glenn Gould Papers, Library and Archives Canada, 1979-20/5,38, 3; $\odot$ 1967, 2005, the Estate of Glenn Gould and Glenn Gould Ltd., courtesy of the Estate of Glenn Gould and Glenn Gould Ltd.

Second the sketch also provides information on the composer's working methods. The Roman numeral I following the words "In any case" refers to the first reel of Gould's taped interview with Wally Maclean and the Arabic number refers to page six of the typed transcript of that reel. In the typescript of this section of the interview (see Plate 4) the beginning of the text fragment is identified with an arrow just above and to the left of the words "in any case" (line 8). This fragments ends with the words "this is hard to get at" followed by a double bar (line 25). Coming back to Plate 3, the indication "II-9," following the words "Now most of us", refers to the transcript of the second reel of recorded material, page 9. This text fragment, from a later part of the interview was inserted just after the words "this is hard to get at" (Plate 4, lines 24-25). In the right margin Gould wrote "Mac 3" indicating that the third text fragment would begin with the words indicated by the arrow "So you begin by saying" (Plate 4, line 25). With these text fragments Gould assembled what we might call the libretto of Maclean's "aria."

of the page Gould underlined the word "aria" and below we find fragments of the epilogue's text: "north that was", "'lets get at it' before W-James", etc. Glenn Gould Papers, document 1979-20/4,104, 1, Library and Archives Canada. 
In the name of all thot's Holy are they, 15 miles avay from this plece callod churbill abooting rockots, canadian ones mark wtill jou Alautte, and Black Brent and what all, into the night sky, to find out how far they go and what they do and yat catoh sowe atmosphere and were they go no doubt and to gat tape -. somshow they get, this all goes on those wbirling tweat things in place celled Digis on tape, I don't know how they do 14 and in uny we oase thl man bes juat told me this is what be $1 \mathrm{~s}$ about (to do) Now I hav to enawer in kind, suroly I have to toll blm how I one to got stuffed away up there. Oh, thia is - 11ttlo harder isn't it because here is a man (you must be tendar to here is man) who has got to $11 \mathrm{~d}$ (with himsele over the next 28 months, I think they let hid you know, get swee pass or some sort of transportation in that tive, but gou wat treat him tenderly you can't lot him have the Narth all in one barrel so to opeak, so what do you

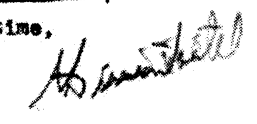
say. Woll, ume, what do you say. I suppose you sort of try and becone truthrul with goureale, this is tough, It is ao neeriy imposstblo that it takes all these miles and all this understanding, and perhaps need for buman company to (porbaps) )ake it possible (when you're anking a trip over the aume track that you caine in on two hours and bey ago.) rtm just guosalng now, thto is hard to

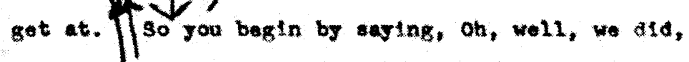
at least some or us thought that this was a challonge a wh1le back. He looks at you sort of -w vell auroly it is a challange now. T mean this is the first the he

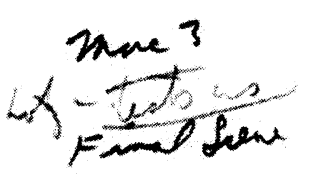
has been on these wo11s that run North and incidentalis

Plate 4. Glenn Gould, The Idea of North, transcript of reel one of Gould's interview of Wally Maclean, page 6, annotated typescript, conserved in the Glenn Gould Papers, Library and Archives Canada, 1979-20/4,95; ( 1967, 2005, the Estate of Glenn Gould and Glenn Gould Ltd., courtesy of the Estate of Glenn Gould and Glenn Gould Ltd. 
Plates $5 \mathrm{a}$ and $5 \mathrm{~b}$ below present the first two pages of the heavily annotated third draft of the epilogue. The numbers in the left margin indicate the succession of text fragments taken from transcribed interviews. The length of these fragments varies considerably. Whereas some are made of only a few sentences (fragment 3 , Plate $5 \mathrm{~b}$ ) or only parts of sentences (fragments 5 and 6 , not shown here), others run on for whole pages (fragment 4). Having selected these text fragments, Gould then proceeded to organize them into the seven paragraphs of the definitive text of the epilogue. These paragraphs do not always coincide with

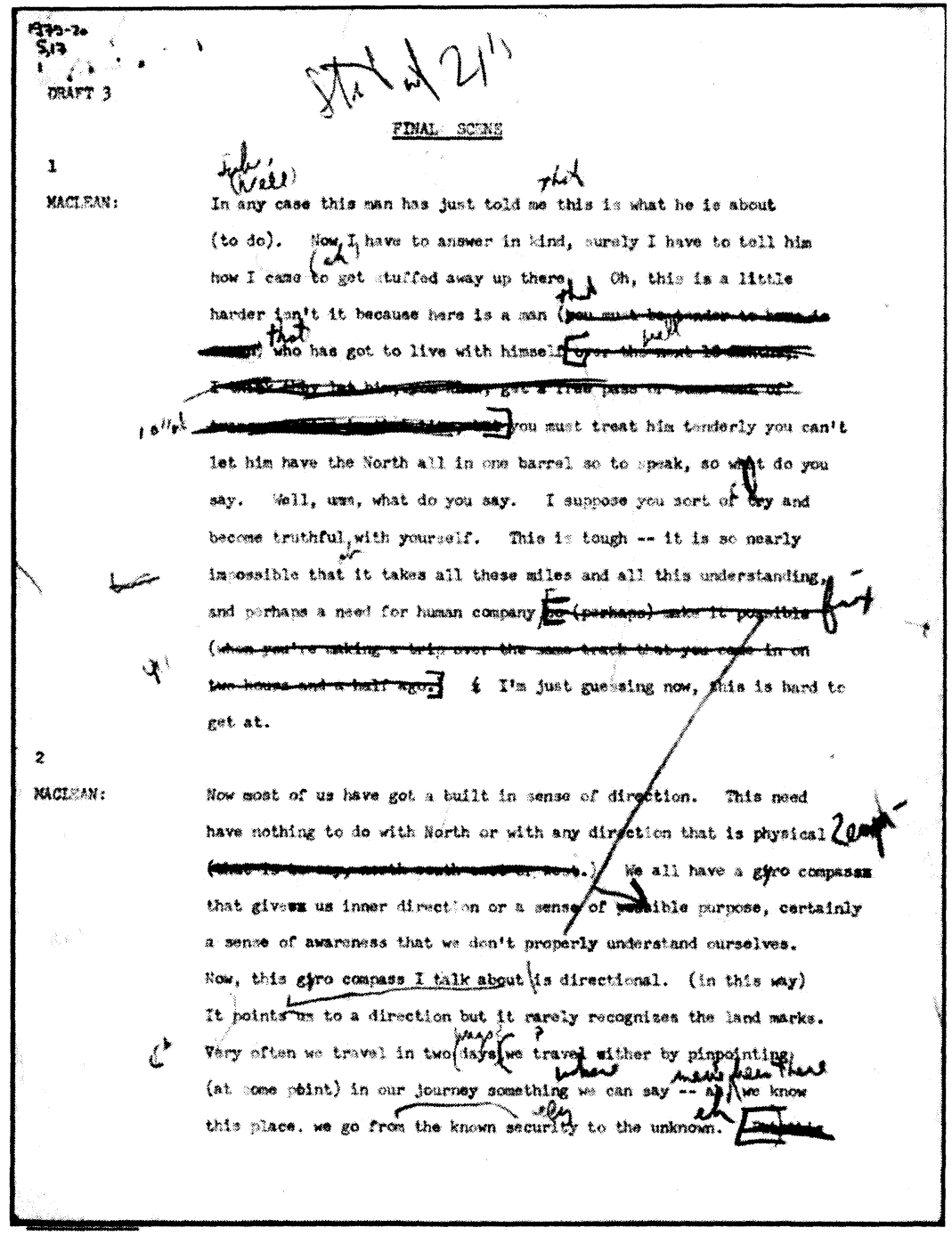

Plate 5a. Glenn Gould, The Idea of North, third draft of the text of epilogue, pages 1-2, annotated typescript, conserved in the Glenn Gould Papers, Library and Archives Canada, 1979-20/4,95; @ 1967, 2005, the Estate of Glenn Gould and Glenn Gould Ltd., courtesy of the Estate of Glenn Gould and Glenn Gould Ltd. 


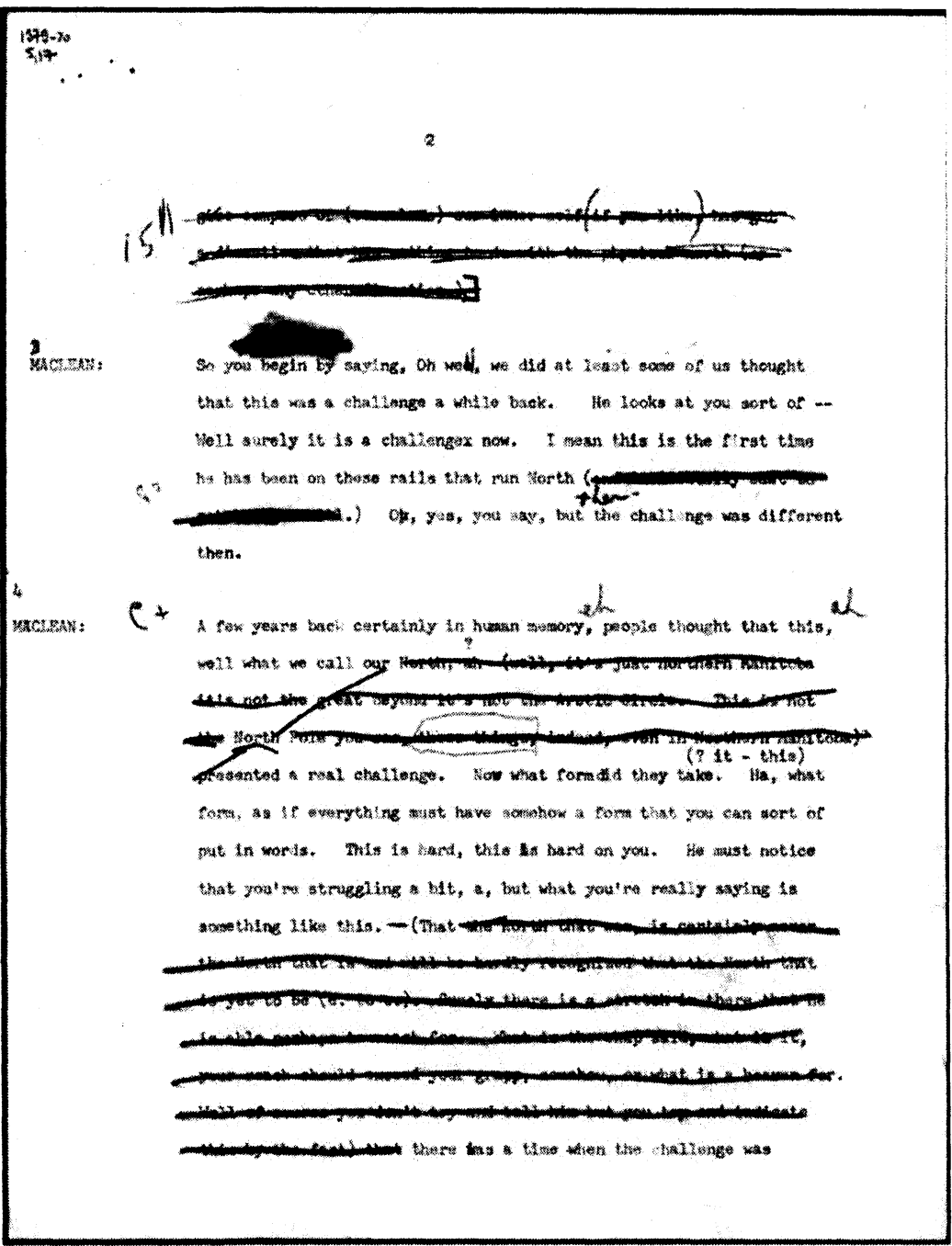

Plate 5b. Glenn Gould, The Idea of North, third draft of the text of epilogue, pages 1-2, annotated typescript, conserved in the Glenn Gould Papers, Library and Archives Canada, 1979-20/4,95; @ 1967, 2005, the Estate of Glenn Gould and Glenn Gould Ltd., courtesy of the Estate of Glenn Gould and Glenn Gould Ltd.

the chosen text fragments. For example, the first two text fragments correspond with the first two paragraphs of Maclean's definitive text (see Plate 5a). By contrast, the third paragraph is made up of text fragment 3 and the first nine lines of text fragment 4.

Friedrich $(1989,205-6)$ observed that, though Maclean's words may sound shrewd or sagacious on first hearing, when carefully examined they actually "come perilously close to gibberish." Indeed he believes that "to prevent us from 
listening too closely", Gould deliberately dubbed the text with "the Artic strains of Sibelius's Fifth Symphony." Others have proposed similar interpretations of the relationship between Maclean's text and Sibelius's music. ${ }^{22}$ When set against information extracted from the study of Gould's sketches, these interpretations of the relationship between text and music are plainly mistaken. The surviving manuscript material clearly shows that Gould carefully whittled down this text to make it conform to the time-constraints of the music. In so doing he underlined and clarified those aspects of the text he wished to bring forward within the symphonic framework. That is to say, he composed an aria for spoken voice by forging text fragments to correspond with his understanding of Sibelius's symphonic form.

The length of the epilogue of North is determined by the duration of Herbert von Karajan's recording of Sibelius's symphony. ${ }^{23}$ The cuts in the text (see Plates $5 a$ and $5 b$ ) were made not just so that the text would fit into the general time envelope of the whole movement, but also so that themes of the text would correspond with the movement's sectional structure as Gould understood it. Among the Glenn Gould Papers conserved at Library and Archives Canada is a pocket score of Sibelius's Fifth Symphony. In the last movement, Gould pencilled in words and at times just syllables from the interview indicating the exact point at which they should occur in relation to Sibelius's music. For example on the first page of the third movement Gould wrote in a decrescendo beginning at rehearsal letter A (bar 26). The decrescendo ends at bar 31, where Gould wrote "22 Mac" (the syllable Mac is encased in a crescendo mark). This indicates that starting with the repeat of the main subject at bar 27 Gould began to partially fade out Sibelius's music in order to make room for Maclean's voice, which fades in at bar 31. Musical form dictates how much text can be used and how it will be disposed in time.

But if music impinges on the text, Gould also uses the text to comment on the music. Gould's relatively conservative reading of the movement as a modified sonata form can be deduced from the correspondences he established between the seven paragraphs of his text and the seven sections of the symphonic movement (see Figure 1 below). ${ }^{24}$ Broadly speaking, Gould organizes the content of

22 Dickenson $(1996,115)$ presents what appears to be an unacknowledged paraphrase of Friedrich's position when he states that "Gould comes perilously close to invoking a kind of monological closure, with the Nordic strains of Jean Sibelius's Fifth Symphony accompanying Wally Maclean's ultimately moralistic musings." McNeilly $(1996,101)$ presents Sibelius's music as "muted background to Wally Maclean's quasi-philosophical reflections on the meaning of 'North'."

23 Except for one spot, the entire third movement of Symphony no. 5 is clearly audible. At rehearsal letter I the dynamic level of the recorded music fades down to such an extent that approximately six bars (280-85) can not be heard. The period of time these bars occupy in the movement is however maintained. The booklet accompanying the CBC recording of The Idea of North provides the following information concerning the Karajan recording of Sibelius's Fifth Symphony used by Gould. "Symphony No. 5 in E Flat, Op. 82 ... Performed by Berlin Philharmonic Orchestra, Herbert von Karajan, conductor. Courtesy of Deutsche Grammophon Gesellschaft and Polygram Records" (Gould 1992). Bazzana $(2003,298)$ reports that the recording was made in 1965.

24 James Hepokoski $(1993,77-78)$ notes that despite the directness of its architecture and effects, the movement is not easily classified among the usual Formenlehre types and in fact analyses of the movement's form are many and varied. 
his text following the movement's thematic contrast. ${ }^{25}$ The first musical theme is associated with the idea of intellectual rationale. During the exposition of this theme, the text introduces the young "research chap" on his way to study the northern lights and in the return of this theme in G-flat major (bars 280-359) the text presents William James's ideas on war. In contrast, the second or Swan theme is associated with Wally Maclean's defence of intuitive common sense (i.e. the "built-in gyro-compass" and his ideas concerning the conflicting relationship between Mother Nature and human nature).

Figure 1:

Comparison of the music and text in the Epilogue of The Idea of North

\begin{tabular}{|l|l|l|l|}
\hline $\begin{array}{l}\text { Sections of the } \\
\text { third movement }\end{array}$ & Bars & $\begin{array}{l}\text { Paragraphs of the } \\
\text { epilogue }\end{array}$ & Content \\
\hline \hline First theme & $1-104$ & $\begin{array}{l}1^{\text {st }} \text { paragraph } \\
\text { (bars 1-110) }\end{array}$ & $\begin{array}{l}\text { Introduction of the young } \\
\text { "research chap" }\end{array}$ \\
\hline Second theme & $104-212$ & $\begin{array}{l}2^{\text {nd }} \text { paragraph } \\
\text { (bars 111-88) }\end{array}$ & $\begin{array}{l}\text { Built-in gyro-compass } \\
\text { providing inner direction } \\
\text { and purpose }\end{array}$ \\
\hline Transition & $213-79$ & $\begin{array}{l}3^{\text {rd }} \text { paragraph } \\
\text { (bars 189-286) }\end{array}$ & $\begin{array}{l}\text { Form and the difficulty } \\
\text { of verbalizing abstract } \\
\text { concepts }\end{array}$ \\
\hline First theme & $280-359$ & $\begin{array}{l}4^{\text {th }} \text { paragraph } \\
\text { (bars 287-368) }\end{array}$ & $\begin{array}{l}\text { William James and the } \\
\text { moral equivalent of war }\end{array}$ \\
\hline Second theme & $360-406$ & $\begin{array}{l}5^{\text {th }} \text { paragraph } \\
\text { (bars 369-441) }\end{array}$ & $\begin{array}{l}\text { Mother nature as a } \\
\text { common enemy }\end{array}$ \\
\hline $\begin{array}{l}\text { Expanded } \\
\text { second theme }\end{array}$ & $407-66$ & $\begin{array}{l}6^{\text {th }} \text { paragraph } \\
\text { (bars 442-66) }\end{array}$ & $\begin{array}{l}\text { Mother nature versus } \\
\text { human nature }\end{array}$ \\
\hline Coda & $467-82$ & $\begin{array}{l}7^{\text {th }} \text { paragraph } \\
\text { (bars 467-82) }\end{array}$ & $\begin{array}{l}\text { William James and the } \\
\text { North }\end{array}$ \\
\hline
\end{tabular}

The text/music relationship is however far more subtle than the above schema is able to represent. By deleting approximately 15 seconds of text from the end of the second paragraph (see Plate $5 b$ ), Gould ends this paragraph with the words, "... we know this place; we go from the known securely to

25 The correspondence is not always exact. As can be seen in Figure 1, the second paragraph begins after the entrance of the second theme and finishes a full 24 bars before the end of the same theme. Nevertheless the general correspondence obtaining between the paragraphs and the sections of Sibelius's music can hardly be seen as accidental. 
the unknown," which, in this context, take on a double meaning. In his interview, Maclean was referring to an intuitive sense of direction (his "builtin gyro-compass"), enabling individuals to confront the challenges of day-today life. Placed in the context of Sibelius's symphonic movement, the text also forewarns the listener that the end of the second theme is imminent. James Hepokoski $(1993,82)$ notes that at precisely this moment the rhythmic intervals of the second theme begin to expand, destabilizing the theme's complex poly-metric structures. In the third paragraph, which roughly corresponds with the transition that precedes the return of the first theme, the text poses the question of form, asking whether everything must have a form that can be expressed verbally (see Plate $5 b$ ). The question coincides with the arrival of a deceptive cadence in $\mathrm{C}$ minor at rehearsal letter $\mathrm{H}$. The A-flat chord in first inversion (bar 242) changes from major to minor (bar 246), which prepares the return of the first subject at rehearsal letter I. As the voice worries about the difficulties of verbally circumscribing abstract concepts, the music moves from the established tonality of $\mathrm{C}$ minor towards the relatively remote tonality of G-flat major, momentarily destabilizing the active listener's tonal bearings.

Clearly, the function of Sibelius's music is neither to cover over Maclean's "gibberish," nor to provide innocuous background accompaniment. Throughout this section, text and music are carefully entwined in a reciprocal running commentary. Bazzana (1997, 87-127) has observed that Gould's performance practice as a pianist entails explicit analytical commentaries on the works he interprets, and his interpretations contain layers of humour and parody, as well as ethical considerations. Furthermore he insists that this content is transmitted musically to the attentive listener through Gould's performance, without reference to liner notes or other printed commentaries. ${ }^{26}$ This is also true of North and the other compositions of the Solitude Trilogy. In these works, Gould's voice is not one voice among many in some kind of proto-post-modern mélange (McNeilly 1996, 100-1). On the contrary, his is the authorial voice of the modernist composer presenting what was then an avant-garde compositional project. ${ }^{27}$

\section{The Production of Place in Music}

The position described at the outset as "sympathetic ambivalence," which understands The Idea of North as at once a documentary, a radio drama and a musical composition is problematic because it does not adequately account for the work's internal coherence. Furthermore, this position is also misleading because it tends to separate the semantic content of the text from the

\footnotetext{
26 Bazzana makes this point with reference to Gould's recording of the Mozart sonatas.

27 As the reader may have guessed by now, I am sceptical of the idea that Western culture is now suffering what Jean-François Lyotard $(1979,11-17)$ called the "post-modern condition". Indeed I remain unconvinced that this ill-defined adjective (post-modern) can be usefully applied to contemporary music (Sallis 2000).
} 
musical aspects of the work. ${ }^{28}$ Fink $(1997,39)$ writes that in this work Gould combined the "form, information and ethical message of modern documentary with the forms and emotional effects of modern music." Music (modern or otherwise) is here understood as merely an assemblage of acoustic structures, the specific meaning of which is encased within those structures and thus separate from the meaning of the text (i.e. the documentary information). This position is of course rooted in the formalist doctrines of the nineteenth century famously summed up by Eduard Hanslick ([1854] 1957, 32): "Forms moved in sounding [tönend bewegte Formen] are the sole and single content and object of music." 29

But as we have seen, the text and music of the epilogue are intimately linked to one another in a reciprocal running commentary. Such a relation also obtains between the text fragments and their musical manipulation in the prologue and in the rest of the work. Trying to separate the texts of the prologue from their musical manipulation would be an extremely difficult if not impossible task. This intimate relationship between text and music is of course not unique to The Idea of North. On the contrary, this condition pertains to vocal music per se, be it Schubert Lieder or Gregorian chant. To the extent that it involves the setting of a text, all vocal music has always been, to paraphrase McNeilly $(1996,101)$, "multiplicitous" in both form and content, and when it is done well the result is always more than the sum of its constituent elements. If the analytical intention is to arrive at what Fink (1997, 36) calls a "unified theory" of the work as a whole, then the separation of the text from its musical manipulation would clearly constitute a distortion of North. As stated above, the challenge facing those who wish to study North is that the musical aspects have not been notated. They exist as recorded sounds and are consequently difficult to grasp and to analyse, but they most certainly are present nonetheless. The rise and fall of Maclean's intonation, the hesitant rhythmic delivery, and the numerous interjections and conjunctions ("ah," "eh," "umm," and "oh well," see Plates 5a and 5b) combine to give the vocal part of the epilogue a distinctly musical character. Indeed, Maclean's voice and the text it imparts are far more important as an expression of personality than as a source of specific information. The reason Friedrich qualified this text as "gibberish", is clearly because he could not hear Maclean singing.

Albrecht Wellmer (2002, 151-56) has proposed that the true "place of art," and specifically of the musical work of art, is that imaginary space between listening subject and the aesthetic object within which a reflexive interplay of formalist and hermeneutic perspectives creates a seemingly endless series of relationships. These relationships constitute our aesthetic experience of the musical works of art, which Wellmer calls, after Adorno, "die Prozessualität der musikalische Erfahrung" (the processional nature of musical experience).

28 Many commentators who subscribe to this position (Dickenson 1996, McNeilly 1996, Fink 1997) concentrate their observations of the work almost exclusively on the text.

29 For a concise, subtle interpretation of this oft-cited postulate, see Dahlhaus (1982, 52-57). 
This concept is not meant to refer to the obvious fact that music (like drama and cinema) becomes manifest through time. Rather, it underscores the dynamic nature of our apprehension of music and indeed all art, be it a photograph or a sonata. Wellmer $(2002,153-54)$ goes on to suggest that the very idea that works have an objective structure located outside of the aesthetic experience (for example in the score) is an illusion. ${ }^{30}$ Everything involved in the manipulation of sound and silence, as well as all possible hermeneutic perspectives that can be brought to bear on this manipulation (historic, biographic, cultural, sociological, and of course geographic) can potentially be part of that aesthetic object we call a work of music. However, in order for this synthesis to occur, these perspectives must be integrated into the aesthetic experience of that object.

Wellmer's position should not be interpreted as an open invitation to indulge in the unlimited semiosis of post-modern misreading. On the contrary, his insistence on the reciprocal relationship between the object (the work) and the listening subject, stipulates that the interpretation of a work of musical art is based on a dialectical relationship between the object and the subject. One of the foundations of Wellmer's work is Arnold Schoenberg's statement $(1992,51)$ that the idea or content (Gedanken) of a work of musical art is the totality of the work. ${ }^{31}$ Theodor Adorno developed this statement by saying that musical content is literally "what is going on" (das Geschehende) in a given work, what happens to its basic material, both technically and intellectually, in the process of its shaping and of its unfolding through time (Paddison 1993, 149-83). Wellmer $(2001,20)$ correctly points out that Adorno was the first to have clearly understood that formalist and hermeneutic approaches to music are not alternative or competing perspectives. On the contrary, this opposition must be overcome in order to understand how works of music are constituted as aesthetic objects in the first place. This is how a sense of time and place is generated in works of art such as North. In art, meaning is not merely constructed out of thin air; it is, or at least it should be, negotiated through a dynamic confrontation involving an attentive, knowledgeable listener actively contemplating an aesthetic object. Thus, the musicality of North is not just one aspect of a complex, syncretic object, as Fink suggests $(1997,35)$. To the extent that the text and its musical manipulation constitute the substance of North, and that the musical aspects of this work are more than empty formal devices or mere background ambience, it is only as music that we can properly apprehend the aesthetic object as a coherent whole. If North constitutes a coherent aesthetic object, then it does so as music.

\footnotetext{
30 This assertion is of course problematic with regard to musical works of the classical canon, because the tonal structure upon which these works are based is surely more that simply a figment of our collective imagination.

31 "Ich selbst betrachte die Totalität eines Stückes als den Gedanken: den Gedanken, den sein Schöpfer darstellen wollte."
} 
Gould once summed up his work in the following terms: "The Idea of North is itself an excuse-an opportunity to examine that condition of solitude which is neither exclusive to the north nor the prerogative of those who go north but which does perhaps appear, with all its ramifications, a bit more clearly to those who have made, if only in their imagination, the journey north" (Page 1984, 393-94). The northern Canadian territories are not documented in North, but this geographic space is evoked through the composition of sound (duration, dynamics, tempo, phrasing, and pitch) and silence, the polyphonic manipulation of voices and the interaction of musical parameters with the semantic content of the text. It is as a whole aesthetic entity that we experience Gould's Idea of North and it is as such that it should be interpreted. It is only as music that we are able to take proper measure of the scope of Gould's achievement.

\section{REFERENCE LIST}

Anhalt, Istvan. 1984. Alternative Voices: Essays on contemporary vocal and choral composition. Toronto: University of Toronto Press.

Barbash, Ilisa and Lucien Taylor. 1997. Cross-Cultural Filmmaking. A Handbook for making Documentary and Ethnographic Films and Videos. Berkeley: University of California Press.

Bazzana, Kevin. 1994. "Gould, Glenn (Herbert)." Die Musik in Geschichte und Gegenwart: allgemeine Enzyklopädie der Musik, Personenteil, vol. 7, ed. L. Finscher, Kassel: Bärenreiter-Metzler, p. 1417.

. 1997. Glenn Gould: The Performer in the Work: A Study of Performance Practice. Oxford: Clarendon Press.

. 2003. Wondrous Strange: The Life and Art of Glenn Gould. Toronto: McClelland \& Stewart Ltd.

Bellemin-Noël, Jean. 1972. Le texte et l'avant-texte. Paris: Larousse.

Benjamin, Walter. 1998. The Origin of German Tragic Drama, John Osborne trans. London: Verso.

Biasi, Pierre-Marc de. 2004. "Towards the Science of Literature: Manuscript Analysis and the Genesis of the Work." Genetic Criticism: Texts and Avant-textes. Jed Deppman, Daniel Ferrer, Michael Groden eds. Philadelphia: University of Pennsylvania Press, 36-68.

Bowen, José A. 1999. "Finding the music in musicology: Performance history and musical works." Rethinking music. Nicholas Cook, Mark Everist eds. Oxford: Oxford University Press, 424-51.

Cook, Nicholas. 2003. "Music as Performance. The Cultural Study of Music: A critical introduction." Martin Clayton, Trevor Herbert, Richard Middleton eds. New York: Routledge, 204-14.

Dahlhaus, Carl. 1982. Esthetics of Music, William Austin trans. Cambridge: Cambridge University Press.

De Benedictis, Angela Ida. 2004a. Radiodramma e arte radiofonica. Storia e funzioni della musica per radio in Italia. Turin: EDT. 
2004b. "Scrittura e supporti nel novecento: alcune riflesioni e un esempio (Ausstrahlung di Bruno Maderna)." La scrittura come rappresentazione del pensiero musicale. Gianmario Borio ed. Turin: EDT, 237-91. . 2005. "Il suono oltre il segno: la carta, i limiti e gli inganni (cinque esempi)." Acoustical Arts and Artifacts. Technology, Aesthetics and Communication 2: 53-65.

Dickinson, Peter. 1996. "Documenting North in Canadian poetry and music." Essays on Canadian Writing 59: 105-22.

Eco, Umberto. 1989. The Open Work, Anna Cancogni trans. Cambridge: Harvard University Press. Press.

Feld, Steven. 1976. "Ethnomusicology and visual communication", Ethnomusicology 20/2: 293-325.

Fink, Howard. 1997. "Glenn Gould's Idea of North: The Artic Archetype and the Creation of a Syncretic Genre." GlennGould 3/2: 35-42.

Friedrich, Otto. 1989. Glenn Gould: A Life and Variations. Toronto: Lester \& Orpen Dennys.

Godlovitch, Stan. 1998. Musical Performance: A philosophical study. London: Routledge.

Gould, Glenn. 1971. "Radio as Music." Cahiers de musique canadienne/The Canada Music Book, 13-30.

. 1992. Glenn Gould's Solitude Trilogy: Three Sound Documentaries. Toronto: CBC Records/Les disques SRC, PSCD 2003-3.

Grésillon, Almuth. 1994. Eléments de critique génétique. Lire les manuscrits modernes Paris: Presses universitaires de France.

Hanslick, Eduard. [1854] 1957. The beautiful in music. Morris Weitz ed. Gustav Cohen trans. New York: Liberal Arts Press.

Hay, Louis. 2004. "Genetic Criticism: Origins and Perspectives." Genetic Criticism: Texts and Avant-textes. Jed Deppman, Daniel Ferrer, Michael Groden eds. Philadelphia: University of Pennsylvania Press, 17-27.

Hepokoski, James. 1993. Sibelius: Symphony No. 5. Cambridge: Cambridge University Press.

Hjartarson, Paul. 1996. "Of inward journeys and interior landscapes: Glenn Gould, Lawren Harris, and The Idea of North." Essays on Canadian Writing 59: 65-86.

Jenny, Laurent. 1996. "Genetic Criticism and its Myths." Yale French Studies 89: 9-25.

Kivy, Peter. 1995. Authenticities: Philosophical reflections on musical performance. Ithaca: Cornell University Press.

Lebrave, Jean-Louis. 1992. "La critique génétique: une discipline nouvelle ou un avatar moderne de la philologie." Genesis : Manuscrits, recherche, invention $1: 33-72$.

Ligeti, György and Rainer Wehinger. 1970. Artikulation Elektronische Musik: ein Hörpartitur. Mainz: Schott. 
Lyotard, Jean-François. 1979. La condition postmoderne. Paris: Les Editions de Minuit.

Maley, Desmond. 2004. "Review of Wondrous Strange: The Life and Art of Glenn Gould." Canadian Book Review Annual, 35.

McNeilly, Kevin. 1996. "Listening, nordicity, community: Glenn Gould's The Idea of North." Essays on Canadian Writing 59: 87-104.

Nattiez, Jean-Jacques. 1996. "The Language of Music in the Twenty-first Century: Gould as a Precursor of Post-modernism?" GlennGould 2: 28-35.

Paddison, Max. 1993. Adorno's Aesthetics of Music. Cambridge: Cambridge University Press.

Page, Tim ed. 1984. The Glenn Gould Reader. New York: Vintage, 1984.

Payzant, Geoffrey. 1978. Glenn Gould, music and mind. Toronto: Van Nostrand Reinhold Ltd.

Pearsall, Judy ed. 1998. The New Oxford Dictionary. Oxford: Oxford University Press.

Pincoe R. and S. C. Willis eds. 1992. Glenn Gould: Descriptive Catalogue of the Glenn Gould Papers/Catalogue raisonné du Fonds Glenn Gould. Ottawa: National Library of Canada.

Rink, John ed. 2002. Musical Performance. A Guide to Understanding. Cambridge: Cambridge University Press.

Roberts, John P. L. and Ghyslaine Guertin eds. 1992. Glenn Gould: Selected Letters. Toronto: Oxford University Press.

Said, Edward W. 1979. Orientalism. New York: Vintage. . 1991. Musical Elaborations. New York: Columbia University Press.

Sallis, Friedemann. 2000. "Le paradoxe postmoderne et l'œuvre tardive de Luigi Nono." Circuit. Musiques contemporaines. Analyses 11/1: 69-84.

Schoenberg, Arnold. 1992. Stil und Gedanke, Ivan Vojtech ed. Frankfurt am Main: Fischer.

Sibelius, Jean. 1926. Symphonie Nr. 5, Op. 82. Copenhagen: William Hansen. Taruskin, Richard. 1995. Text and act. Essays on Music and Performance. Oxford: Oxford University Press.

Wellmer, Albrecht. 2001. "Sprache - (Neue) Musik - Kommunikation." L'orizzonte filosofico del comporre nel ventesimo secolo. Gianmario Borio ed. Bologna: Società editrice il Mulino.

2002. "Das musikalische Kunstwerk." Falsche Gegensätze. Zeitgenössischen Positionen zur philosophischen Ästhetik, Ruth Sonderegger and Andrea Kern eds. Frankfurt a.M.: Suhrkamp.

\section{ABSTRACT}

This paper will examine the notion that music can create a sense of place and identity. The object of study is Glenn Gould's Idea of North, which is made up primarily of texts extracted from interviews. Gould manipulated this material using techniques and concepts to produce what he would later call contrapuntal radio. It was through this technical manipulation, as much as through 
the content of the texts themselves, that Gould was able to express his 'idea of north'. A critical examination of these musical techniques provides an interesting example of how music is able to produce a sense of place and identity.

\section{RESUME}

Cet article étudie la notion que la musique peut créer un sentiment de localisation et d'identité. Son objet d'étude est Idea of North de Glenn Gould, qui est essentiellement rédigé à partir de textes provenant d'entretiens. Gould manipule ce matériel avec des techniques et concepts permettant la réalisation de ce qu'il appellera par la suite " contrapuntal radio " [radio contrapuntique]. C'est grâce à cette manipulation technique, tout autant qu'en se servant du contenu des textes, que Gould sera en mesure d'exprimer son "idée du Nord" ". Un examen critique de ces techniques musicales présentent ainsi un exemple intéressant de la manière dont la musique parvient à produire un sentiment de localisation et d'identité. 